\title{
Preoperative Assessment of Different Treatment Modalities in Bronchial Asthma Patients
}

\author{
*Kawther A. Azzam M.D. and **Sahar S. Khattab MD. \\ Departments of *Anaesthesiology and **Clinical Pathology \\ Faculty of Medicine for Girls, Al-Azhar University
}

\begin{abstract}
:
This study was performed to assess the effectiveness of acupuncture and medical therapies of bronchial asthma preoperatively. Sixty patients suffered from mild to moderate bronchial asthma and coming for elective operations were chozen from the outpatient clinic of Al-Zahraa University Hospital. Patients were randomly divided into three equal groups $(\mathrm{n}=20$ each). Group I patients (drug group) received oral theophylline and Salbutamol (ventolin) inhaler according to the needs. Group II patients (drug +ear acupuncture group) received same medical treatment as in group I and added ear acupuncture. Group III patients (drug + ear and body acupuncture group) received same medical treatment as in group I and II and added ear and body acupuncture. Ventilatory function tests through spirometer and interleukin-13 estimation were performed before treatment and after two weeks of treatment. Improvement of subjective and objective parameters had occurred with significant decrease in the mean serum level of interleukin-13 and decrease in the mean number of using b-agonist puffs after two weeks of treatment in the three groups, with the best results being in group III than in group II and then in group I.

Conclusion: Interleukin-13 estimation togheter with ventilatory function tests is a useful parameter for pre-operative assessment and evaluation of asthmatic patients. Also medication was significantly reduced when combined with acupuncture.
\end{abstract}

\section{Introduction}

The American Thoracic Society (1987) defined bronchial asthma as a clinical syndrome characterized by increased responsiveness of tracheobronchial tree to a variety of stimuli and manifested by widespread narrowing of the airways that changes in severity either spontaneously or as result of therapy.

Many cells and cellular elements play a role in asthma in particular mast cells, eosinophils, $\mathrm{T}$ lymphocytes, macrophges, neutrophils and epithelial cells. Mast cell activation can occur through the crosslinking of high affinity $\operatorname{IgE}$ receptors on the cell surface or the interaction of other stimuli such as neuropeptide substance $\mathrm{P}$ with the mast cell membrane Each result in mast cell degeneration and release of its mediators, these mediators are either performed molecule, found within the mast cell granules (histamine, neutral protease and proteoglycans_ or newly generated molecules (prostaglandins, leukotrienes and cytokines) ${ }^{(1)}$ These released inflammatory mediators from mast cells contribute to bronchocons triction, inflammatory oedema, mucous secretion and activation of secondary effector cells ${ }^{(2)}$

Cytokines play an integral role in the coordination and persistence of the inflammatory process in the chronic 
inflammation of the airways in asthma since they are capable of inducing many of the pro-inflammatory effects charac teristics of their disease ${ }^{(3)}$. Not only cytokines involved in maintaining the chronic inflammatory process, they are also responsible for the initiation of the early stage of this process ${ }^{(4)}$.

Interleukin-13 (IL-13) is a protein produced mainly by activated $\mathrm{T}$ lymphocytes and mastocytes in response to antigen specific stimuli IL13 shows significant consequence and structural homology with IL-4 ${ }^{(5)}$.

Homer et al. ${ }^{(6)}$ found that IL-13, a key mediator Th2 (T-helper lymp hocytes) mediated immunity, contr ibutes to the pathogenesis of asthma and other pulmonary diseases may therefore play a central role in chronic pulmonary conditions in which fibrosis, type II cell hypertrophy and surfactant accumulat ion occur.

Traditionally acupuncture means stimulation of specific points on the surface of the body in order to produce many regulatory effects on the functions of internal organs. Bronchial asthma is one of the major indications for acupuncture in disorders of internal organs. The selection of proper points has been as important as the correct type of stimulation either reinforcement or sedation ${ }^{(7)}$.

The objective of the present study was to assess the effectiveness of non traditional (acupuncture) and traditional (medical treatment) therapies of bronchial asthma to decrease side effects complications and cost of management.

\section{Patients and Methods}

After approval of the Local Ethics Committee, informed written consents were obtained from 60 patients of both sexes, aged between 25-65 years, suffered from mild to moderate bronchial asthma (ASA I, II) and coming for elective operation at outp atient clinic of Al-Zahraa University Hospital.

Mild asthmatics were selected by history taking (day time symptoms greater than twice per week but less than once per day and or night time symptoms greater than twice per month and FEV $1>80 \%$ of normal). Moderate asthmatics were selected by history taking (day time symptoms or night time symptoms more than once per day, FEV1 is $>60 \%$ but $<80 \%$ of normal)

Exclusion criteria included patients with severe bronchial asthma (continual daily symptoms or frequent night time symptoms and FEV1 is $<60 \%$ of normal), patients who were smokers or who had dusty jobs, patients who had chest infection or general medical problems.

Patients were randomly divided into three equal groups ( $\mathrm{n}=20$ each).

Group I patients (drug group) patients were treated by oral theophylline 5-10 $\mathrm{mg} / \mathrm{Kg} /$ day) tablets in divided doses orally/12 hours, In addition to salbutamol (ventolin) inhaler $0.1 \mathrm{mg} /$ puff during attacks as needed the treatment continued for 2 weeks.

Group II patients (drug +ear acupuncture group) were treated by same medical treatment as in group I and added ear acupuncture. The following ear 3 points are used (Fig. 1).

1. Shenman point (ear point 55) to decrease excitation.

2. Lung point (ear point 101) to produce bronchodilatation

3. Dingchuan point (ear point 31) soothing or calming asthma.

The auricle was disinfected, permanent disposable sterile press steel acupuncture needles $(0.22 \mathrm{~mm} \times 1.5$ $\mathrm{mm})$ were fixed with sticking plaster in one ear for one week and then another needles were fixed in the other ear for 
the second week. The patients were asked to press each of the points themselves 3 times a day, with a pulsating movement of the index finger.

Group III patients (drug + ear and body acupuncture group) were treated by same medical treatment as in group I, II and added ear and body acupuncture. Ear acupuncture method as before. Body acupuncture method as follows.

\section{The body points used were:}

1. Baihui (Du 20) ${ }^{(9)}$ Fig. (2): The best tranquilizing and sedative point of the body.

Location: On the vertex of the skull 5 cun (Chinese inch) behind the anterior hairline in the midline.

2. Shanzhong (Ren 17) ${ }^{(9)}$ (Fig. $3)$ : Influential point for the respiratory system.

\section{Location:}

On the sternum midway the two nipples at the level of the $4^{\text {th }}$ intercostals space

3. Dingchuan (Ex.17) ${ }^{(10)}$ (Fig. 4)

Location: 0.5 Cun lateral to the mid point between the dorsal spines of the $7^{\text {th }}$ cervical vertebra (vertebral prominence) and the $1^{\text {st }}$ thoracic vertebra.
4. lieque
$($ Lu. 7$)\left({ }^{9}\right)($ Fig.

Location 1.5 Cun (2 finger breadths) from the wrist joint crease on the lateral border of the forearm.

5. Zhongfu (Lu.1) ${ }^{(9)}$ (Fig.6)

Location: At the level of the interspace between the $1^{\text {st }}$ and $2^{\text {nd }}$ ribs, 6 Cun lateral to the midline. The area was disinfected before puncture with $0.3 \mathrm{mmx} \quad 30 \mathrm{~mm}$ ) stainless steel disposable acupuncture needles
Shanzhong (Ren 17) point and Zhongfu (Lu1) point were connected to KWD808 multi purpose health device for electrical stimulation to acupuncturte points using the continous wave. The other 3 points were rotated by thumb and index finger for 5 seconds every setting. (Three settings 20-25 min each per week for 2 weeks)

Methods: Patients were avoided from exercise for one hour before physical examination. Ventilatory function tests, through spirometer (Spirometer 3000) for measurement of FVC and FEV1 (and also the predicted normal value) before the treatment and after 2 weeks of treatment. Blood samples $2 \mathrm{ml}$ from every patient at the same day centrifuged for separation of serum within one hour of collection and stored at $-20^{\circ} \mathrm{C}$ (frozen) till collection of the samples from all patients for IL-13 immunoassay (Elisa technique) before the treatment and another sample after 2 weeks.

The data were collected coded and analysed using Statistical Package of Social Science (SPSS). Quantitative data were summarized as mean \pm standard deviation (SD) and compared by student-t, ANOVA, LSD multiple comparisons tests and correlation results were expressed as mean \pm SD and \% change. For all statistical comparisons probability of $\mathrm{P} \leq 0.05$ was considered significant.

\section{Results}

Comparison of means of age (year), body mass index (BMI) $(\mathrm{Kg} / \mathrm{m} 2)$ and duration of illness (year) in different study groups which were insignificant as shown in table (1) 

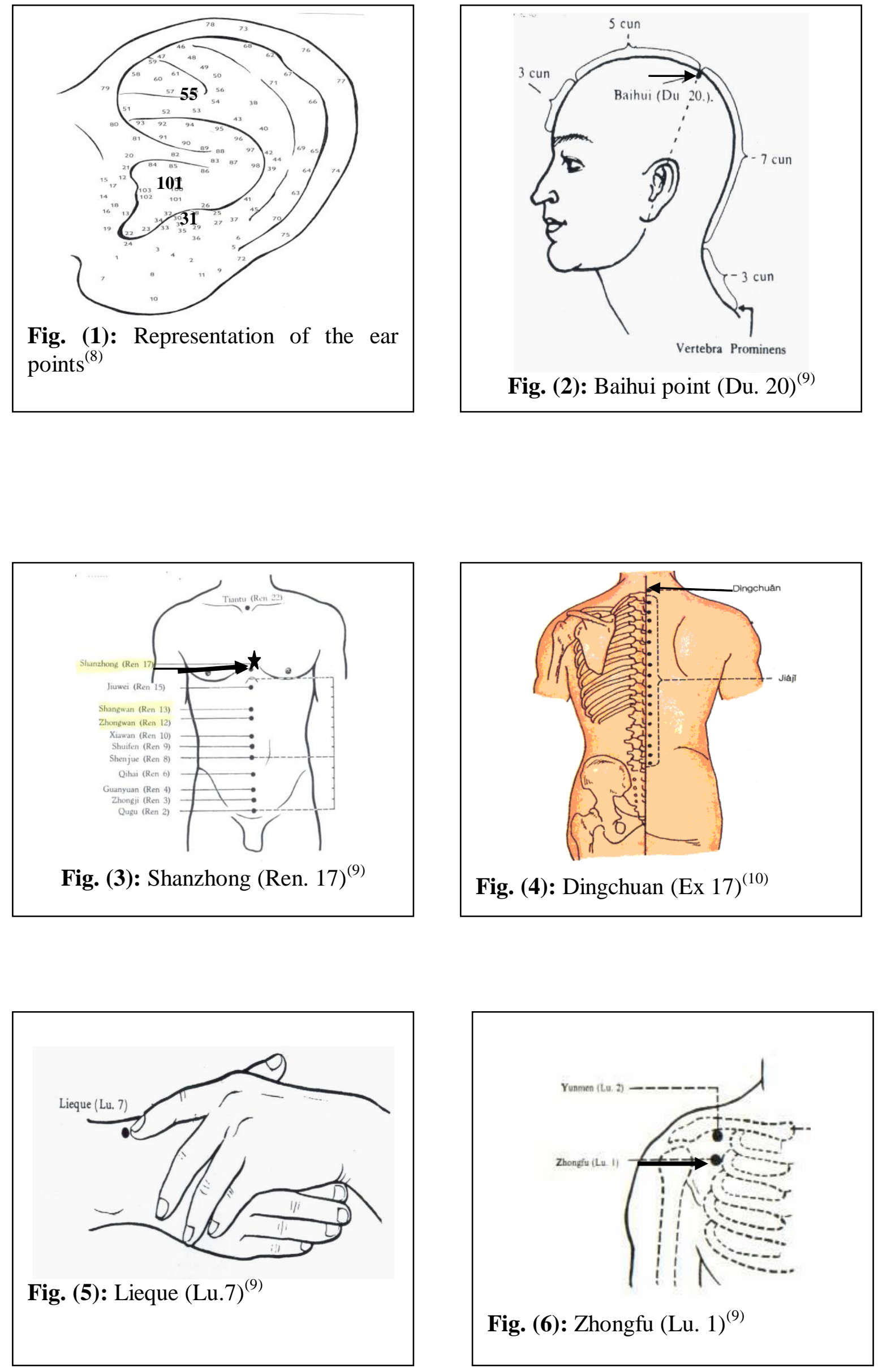


\section{Kawther \& Sahar}

Table (1): ANOVA to compare mean of age (y), BMI $(\mathrm{kg} / \mathrm{m} 2)$ and duration of illness (y) of different sudy groups:

\begin{tabular}{|l|l|l|l|l|l|}
\hline Variable & Group & Mean & SD & F-value & P-value \\
\hline Age (years) & I $(\mathrm{n}=20)$ & 34.30 & 10.50 & 0.45 & 0.77 \\
& II(n=20) & 37.55 & 12.92 & & (n.s) \\
& III(n=20) & 35.12 & 11.08 & & \\
\hline BMI $(\mathrm{kg} / \mathrm{m} 2)$ & I(n=20) & 28.81 & 5.49 & 0.90 & 0.47 \\
& II(n=20) & 26.61 & 5 & & (n.s) \\
& III(n=20) & 27.25 & 4.83 & & \\
\hline Duration & I(n=20) & 9.60 & 8.35 & 0.04 & 0.99 \\
(years) & II(n=20) & 9.45 & 7.86 & & (n.s) \\
& II(n=20) & 10.35 & 8.32 & & \\
\hline
\end{tabular}

$\mathrm{P} \leq 0.05$ is significant $\quad \mathrm{ns}=$ non Significant

In the present study, there was \% improvement of most symptoms and signs in all groups, after 2 weeks of treatment the best results were in group III as shown in table (2)

Cough had been reduced from $100 \%$ (20p) in each of three groups to $25 \%$ (5p), 20\% (4p) and 15\% (3p.) in groups I, II, III respectively.

Expectoration had been reduced from $80 \%$ (16 p) in each one of three groups to $25 \%$ (5P.), $20 \%$ (4p.) and $15 \%(3 \mathrm{P}$.) in groups I, II, III respectively.

Breathlessness was reduced from $100 \%$ (20P.) in each one of three groups to $40 \%(8 \mathrm{P}),. 30 \%(6 \mathrm{P})$ and
$15 \%$ (3 P.) in groups I, II, III respectively.

Wheeze was reduced from $70 \%$ (14 P.) to $25 \%$ (5 P) in group I and from $70 \%$ (14 P.) to $20 \%$ (4 p) in group II and from $75 \%(15$ p.) to $15 \%(3 \mathrm{p})$ in group III.

Vesicular breathing was reduced from $100 \%$ (20P.) in each one of three groups to $30 \%$ (6 P.), $20 \%$ (4 P.) and $15 \%$ (3 P.) in groups I, II, III respectively.

Rhonchi was reduced from $70 \%$ (14 P.) to $20 \%$ (4 P.) in group I, from $60 \%$ (12 P.) to $15 \%$ (3 P.) in group II and from $75 \%(15 \mathrm{P})$ to $15 \%(3 \mathrm{P}$.$) in$ group III.

Table (2): Summary of the number and \% of patients with most symptoms and signs before treatment and after 2 weeks of treatment in different study groups (Chi. Square test).

\begin{tabular}{|c|c|c|c|c|c|c|c|c|}
\hline & \multirow[b]{2}{*}{ Group } & \multirow[b]{2}{*}{ Time } & \multicolumn{4}{|c|}{ Symptoms } & \multicolumn{2}{|c|}{ Signs } \\
\hline & & & Cough & $\begin{array}{l}\text { Expecto- } \\
\text { ration }\end{array}$ & $\begin{array}{l}\text { Breath- } \\
\text { lessness }\end{array}$ & Wheeze & $\begin{array}{l}\text { Vesicular } \\
\text { Breathing }\end{array}$ & Rhonchi \\
\hline \multirow{3}{*}{ 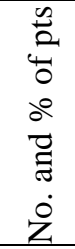 } & I & $\begin{array}{l}\text { Before } \\
\text { After }\end{array}$ & $\begin{array}{l}20(100 \%) \\
5(25 \%)\end{array}$ & $\begin{array}{l}16(80 \%) \\
5(25 \%)\end{array}$ & $\begin{array}{l}20(100 \%) \\
8(40 \%)\end{array}$ & $\begin{array}{l}14(70 \%) \\
5(25 \%)\end{array}$ & $\begin{array}{l}20(100 \%) \\
6(30 \%)\end{array}$ & $\begin{array}{l}14(70 \%) \\
4(20 \%)\end{array}$ \\
\hline & II & $\begin{array}{l}\text { Before } \\
\text { After }\end{array}$ & $\begin{array}{l}20(100 \%) \\
4(20 \%)\end{array}$ & $\begin{array}{l}16(80 \%) \\
4(20 \%)\end{array}$ & $\begin{array}{l}20(100 \%) \\
6(30 \%) \\
\end{array}$ & $\begin{array}{l}14(70 \%) \\
4(20 \%)\end{array}$ & $\begin{array}{l}20(100 \%) \\
4(20 \%)\end{array}$ & $\begin{array}{l}12(60 \%) \\
3(15 \%) \\
\end{array}$ \\
\hline & III & $\begin{array}{l}\text { Before } \\
\text { After }\end{array}$ & $\begin{array}{l}20(100 \%) \\
3(15 \%)\end{array}$ & $\begin{array}{l}16(80 \%) \\
3(15 \%)\end{array}$ & $\begin{array}{l}20(100 \%) \\
3(15 \%)\end{array}$ & $\begin{array}{l}15(75 \%) \\
3(15 \%)\end{array}$ & $\begin{array}{l}20(100 \%) \\
3(15 \%)\end{array}$ & $\begin{array}{l}15(75 \%) \\
3(15 \%)\end{array}$ \\
\hline \multicolumn{2}{|l|}{ Sig. } & $\begin{array}{l}\mathrm{X} 2 \\
* \mathrm{P} \\
\end{array}$ & $\begin{array}{l}0.42 \\
* \mathrm{P}>0.05\end{array}$ & $\begin{array}{l}0.4 \\
* \mathrm{P}>0.05\end{array}$ & $\begin{array}{l}1.8 \\
* \mathrm{P}>0.05\end{array}$ & $\begin{array}{l}0.5 \\
* \mathrm{P}>0.05\end{array}$ & $\begin{array}{l}0.87 \\
* \mathrm{P}>0.05\end{array}$ & $\begin{array}{l}0.18 \\
* \mathrm{P}>0.05\end{array}$ \\
\hline
\end{tabular}

$* \mathrm{P}=$ non significant value to compare each group with preoperative value 
- The results of the mean value of $\mathrm{O} 2 \%$ saruration before treatment and after 2 weeks of treatment showed significant improvement in different study groups. As showed in tab (3) and Fig. (7).

Table (3): There was significant difference between $\mathrm{O} 2 \%$ saturation before and after 2 weeks of treatment in different study groups (paired sample T test)

\begin{tabular}{|c|c|c|c|c|c|c|}
\hline Group & $\begin{array}{l}\text { O2\% } \\
\text { Before }\end{array}$ & $\begin{array}{l}\text { O\% } \\
\text { After }\end{array}$ & $\begin{array}{l}\text { Mean } \\
\text { Difference }\end{array}$ & $\begin{array}{l}\text { SD. of } \\
\text { Difference }\end{array}$ & t-value & P-value \\
\hline I & $97.9(0.64)$ & $98.7(0.66)$ & +0.80 & 0.77 & 4.66 & $0.000 *$ \\
\hline II & $98(0.82)$ & $98.8(077)$ & +0.85 & 0.81 & 6.68 & $0.000 *$ \\
\hline III & $98(0.86)$ & $98.9(1.04)$ & +0.85 & 0.67 & 5.67 & $0.000 *$ \\
\hline
\end{tabular}

$\mathrm{P} \leq 0.05$ is significant $(*=$ Significant $)$

Fig. (7): O2\% saturation before treatment and after 2 weeks of treatment in different study groups

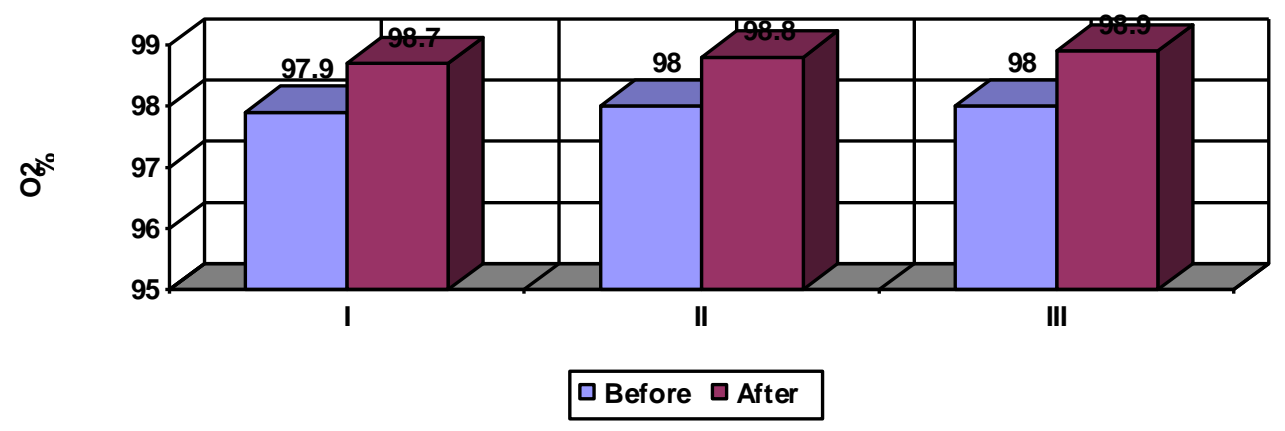

The results of the mean value of FEV1 (L) and FVC (L) showed marked significant improvement in different study groups.(table 4 \&fig 8a )

Table (4): Comparison of mean FEV1(L) and FVC (L) before treatment and after 2 weeks of treatment (with SD) in different study groups (Paired sample T-test).

\begin{tabular}{|l|l|l|l|l|l|l|l|}
\hline Groups & Variable & Before & After & $\begin{array}{l}\text { Mean } \\
\text { difference }\end{array}$ & $\begin{array}{l}\text { SD. of } \\
\text { difference }\end{array}$ & t-value & P-value \\
\hline I & FEV1(L) & $1.47 \pm 0.41$ & $1.93 \pm 0.53$ & \pm 0.46 & 0.19 & 10.96 & $0.000^{*}$ \\
II & & $1.57 \pm 0.52$ & $2.2 \pm 0.64$ & \pm 0.24 & 0.24 & 11.33 & $0.000^{*}$ \\
III & & $1.36 \pm 0.38$ & $2.08 \pm 0.53$ & \pm 0.72 & 0.22 & 14.38 & $0.000^{*}$ \\
\hline I & FVC(L) & $2.55 \pm 0.64$ & $2.64 \pm 0.62$ & \pm 0.08 & 0.06 & 5.96 & $0.000^{*}$ \\
II & & $2.75 \pm 0.77$ & $2.9 \pm 0.74$ & \pm 0.14 & 0.28 & 2.27 & $0.035^{*}$ \\
III & & $2.41 \pm 0.57$ & $2.64 \pm 0.57$ & \pm 0.18 & 0.18 & 5.46 & $0.000^{*}$ \\
\hline
\end{tabular}

$\mathrm{P}<0.05$ is significant $(*=$ significant $)$

Fig. (8a): Mean FEV1(L) before treatment and after 2 weeks of treatment in different study groups.

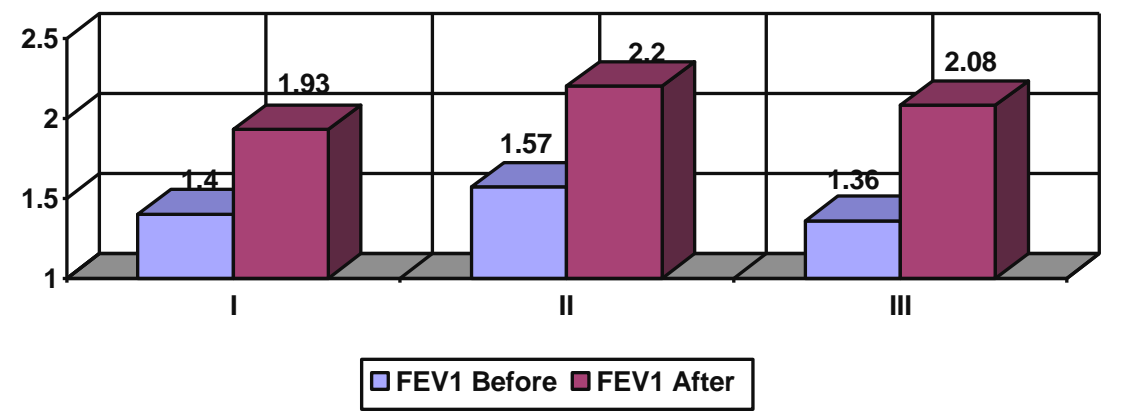




\section{Kawther \& Sahar}

Fig. (8b): Mean FVC (L) before treatment and after 2 weeks of treatment in different study groups.

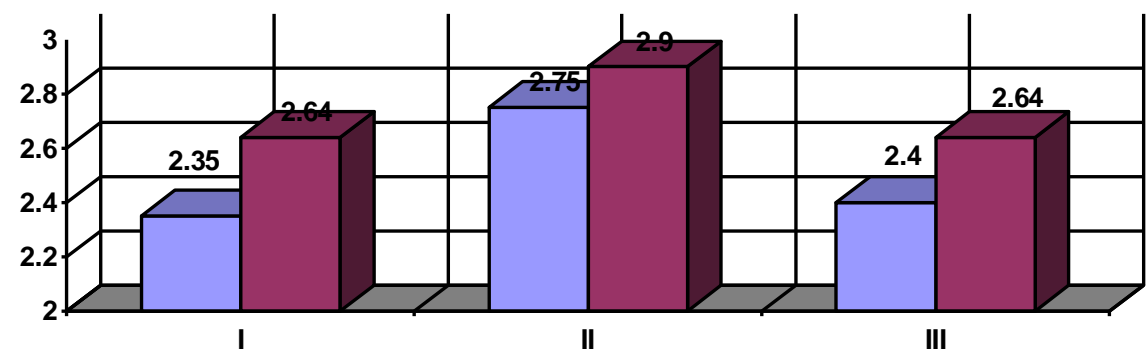

\section{口 FVC Before $\square$ FVC After}

- The results of the mean value of FEV1\% (FEV1/FVCx 100) showed significant improvement in each group of different study groups. The best result of increase of the mean FEV1\% after 2 weeks of treatment were in group III which increased from $56.16 \%$ to $78.45 \%$ $(+22.29 \%, \pm$ SD 5.32). The details were show with $\%$ increase and SD in tab. (5) and fig. (9a,b).

Table (5): Mean FEV1\% and \% increased (with SD) before treatment and after 2 weeks of treatment in different study groups.

\begin{tabular}{|c|c|c|c|c|c|c|}
\hline Group & Before & After & $\begin{array}{l}\% \text { increase } \pm \\
\text { SD }\end{array}$ & $\begin{array}{l}\text { Confidence } \\
\text { interval } \\
\text { Difference }\end{array}$ & t-value & $\mathrm{P}$-value \\
\hline I & $57.5(3.51)$ & $72.7(6.07)$ & $15.2(5.12)$ & $12.83-17.63$ & 13.29 & $0.000^{*}$ \\
\hline II & $56.4(6.07)$ & $75.0(7.21)$ & $18.6(6.01)$ & $15.78-21.40$ & 13.85 & $0.000 *$ \\
\hline II & $56.2(5.34)$ & $78.5(4.63)$ & $22.3(5.32)$ & $19.82-24.78$ & 18.83 & $0.000 *$ \\
\hline
\end{tabular}

Fig. (9a): FEV1\% before treatment and after 2 weeks of treatment in different study groups.

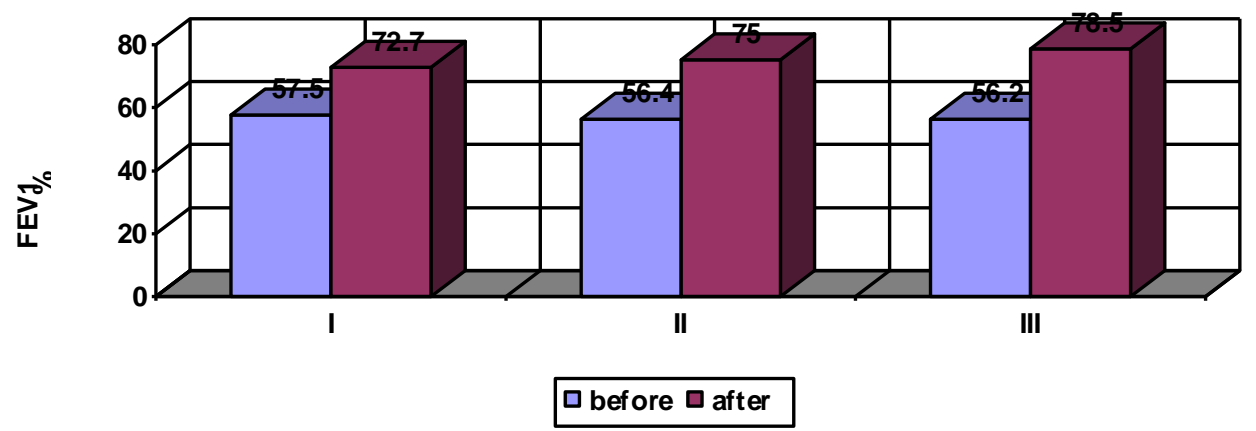

Fig. (9b): Mean $\mathrm{FEV}_{1} \%$ (increase) in different study groups 


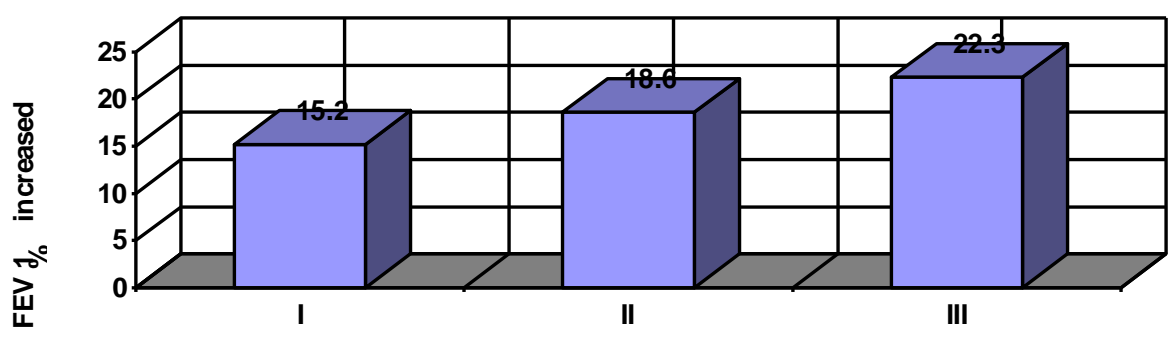

- The mean, value of FEV1\% were significantly improved between groups by ANOVA as shown in tab (6a) and also by LSD multiple comparison tests between each group and the others. The details were shown in tab $(6 a, b)$.

Table (6a): ANOVA to compare means of FEV1\% increase in different study groups.

\begin{tabular}{|l|l|l|l|l|l|}
\hline Variable & Group & Mean & SD & F-value & P-value \\
\hline FEV1\% & I & 15.22 & 5.12 & 9.38 & $0.000^{*}$ \\
(difference) & II & 18.58 & 6.01 & & \\
& III & 22.29 & 5.32 & & \\
\hline
\end{tabular}

$\mathrm{P} \leq 0.05$ is significant $=(*=$ significant $)$

Table (6b): LSD multiple comparison test to compare FEV1\% difference in different study groups.

\begin{tabular}{|l|l|l|l|}
\hline Group & Comparison group & Mean Difference & P-value \\
\hline I & II & 3.36 & $0.04^{*}$ \\
& III & 7.06 & $0.000^{*}$ \\
\hline
\end{tabular}

$\mathrm{P} \leq 0.05$ is significant $(*=$ significant $)$

- The results of the change in the mean level of serum of IL13 (pg/ml) with SD before treatment and after 2 weeks of treatment showed significant decrease $(\mathrm{P} \leq 0.05)$ in different study groups as follow: Group I decreased from $2.020 \mathrm{pg} / \mathrm{ml}$ (1.371) to $0.267 \mathrm{pg} / \mathrm{ml}(0.393)$, Group II was $2.363 \mathrm{pg} / \mathrm{ml}$ (1.433) to $0.165 \mathrm{pg} / \mathrm{ml}(0.321)$ and Group III was $2.418 \mathrm{pg} / \mathrm{ml}$ (2.235) become $0.063 \mathrm{pg} / \mathrm{ml}$ (0.208). The best result recorded were in group III and then in group II as shown in tab (7) and (Fig. 10a,b).

Table (7): Paired Sample T-test to compare IL-13 (pg/ml) before treatment and after 2 weeks of treatment in different study groups

\begin{tabular}{|l|l|l|l|l|l|l|}
\hline Group & Before & After & $\begin{array}{l}\text { Mean } \\
\text { Difference }\end{array}$ & $\begin{array}{l}\text { SD of } \\
\text { Difference }\end{array}$ & t-value & P-value \\
\hline I & $2.020(1.371)$ & $0.267(0.393$ & -1.75 & 1.29 & 6.13 & $0.000^{*}$ \\
II & $2.363(1.433)$ & $0.165(0.321)$ & -2.20 & 1.33 & 7.37 & $0.000^{*}$ \\
III & $2.418(2.235)$ & $0.063(0.208)$ & -2.35 & 2.22 & 4.73 & $0.000^{*}$ \\
\hline
\end{tabular}

$\mathrm{P}<0.05$ is significant $(*=$ significant $)$

Fig.(10a): The mean serum level of IL13 (pg/ml) before treatment and after 2 weeks of treatment in different study groups 


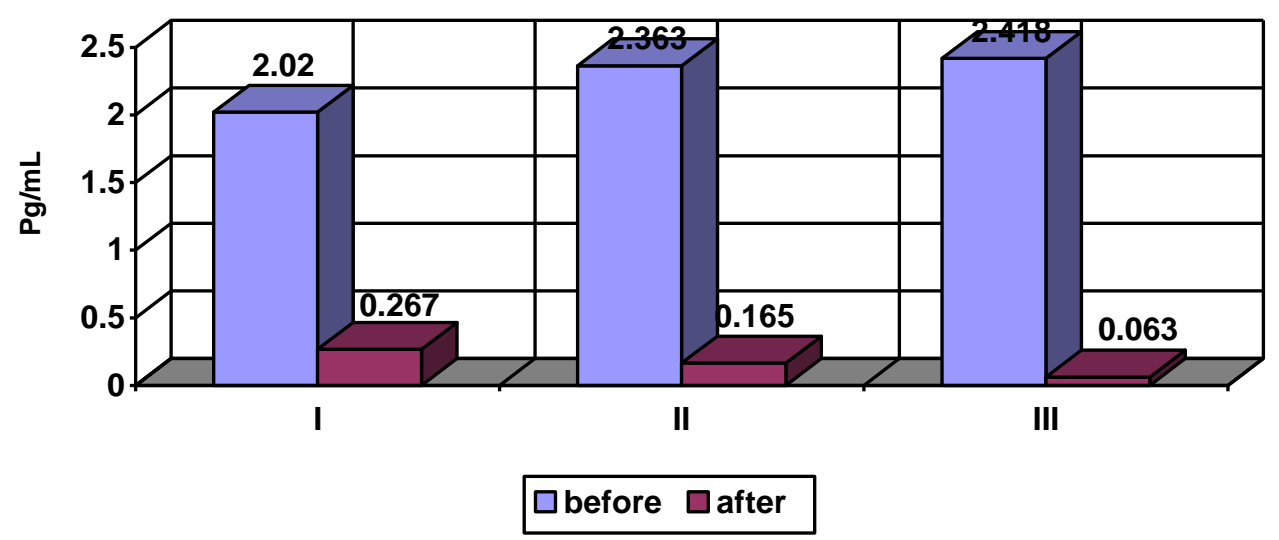

Fig. (10b): Mean difference of decrease in IL13 (pg/ml) in different study groups.

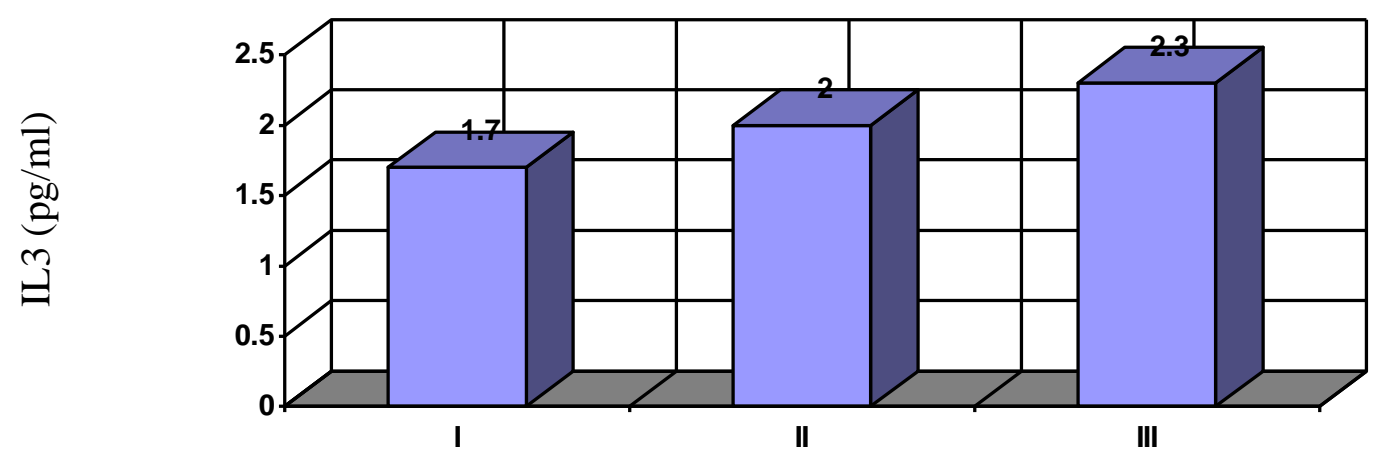

- There was insignificant different -ces between groups by ANOVA for the mean serum of decrease of IL13 ( $\mathrm{pg} / \mathrm{ml})$ before treatment and after 2 weeks of treatment in different study groups. The details were shown in table (8).

Table (8): Comparison of means of IL-13 (pg/ml) decreases before treatment and after 2 weeks of treatment in different study groups (Kruskall wall's test).

\begin{tabular}{|l|l|l|l|l|l|}
\hline Variable & Group & Mean & SD & F-value & P-value \\
\hline IL 13 & I (n=20) & 1.75 & \pm 1.28 & 0.9 & 0.4 \\
& II(n=20) & 2.20 & \pm 1.33 & & (ns) \\
& III $(\mathrm{n}=20)$ & 2.35 & \pm 2.22 & & \\
\hline
\end{tabular}

$\mathrm{P} \leq 0.05$ is significant $\mathrm{ns}=$ nonsignificant

- Comparison of the (mean $+\mathrm{SD}$ ) of puffs used/patient/2 weeks treatment showed significant difference between the three groups The best result were in group III, then in group II, Then in group I.(table 9 , fig 11)

Table (9a): Compareison of mean of number of puff/patient/2 weeks of study groups I, II and III. (ANOVA Test).

\begin{tabular}{|l|l|l|l|l|l|}
\hline Variable & Group & Mean & SD & F-value & P-value \\
\hline No. & $\mathrm{I}(\mathrm{n}=20)$ & 26.55 & 8.48 & 59.50 & $0.000^{*}$ \\
Puff/patient/2 & $\mathrm{II}(\mathrm{n}=20)$ & 9.70 & 6.73 & & \\
weeks & $\mathrm{III}(\mathrm{n}=20)$ & 4.90 & 3.62 & & \\
\hline
\end{tabular}


$\mathrm{P}<0.05$ is significant $(*=$ significant $)$.

Fig. (11): The mean number of puffs used/patient/2 weeks treatment in study groups namely I, II and III.
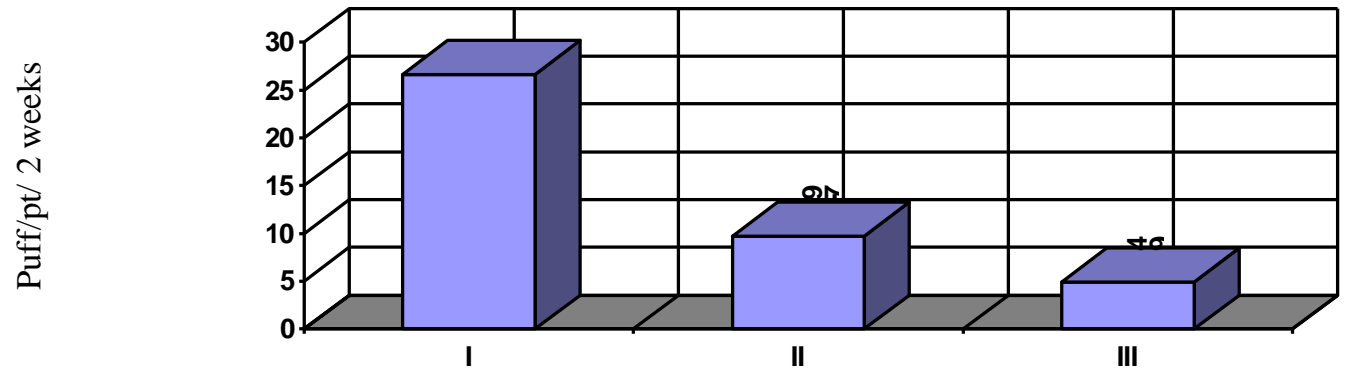

- Comparison between these groups (I, II and III) by LSD multiple comparison tests for the mean number of difference of puffs used/patient/2weeks showed that there was significant difference between these groups as shown in tab (9b).

Table (9b): LSD Multiple Comparison Test to compare number of puff/patient/ 2 weeks in study groups.

\begin{tabular}{|l|l|l|l|}
\hline Group & Comparison group & Mean Difference & P-value \\
I & II & 16.85 & $0.000^{*}$ \\
II & III & 21.65 & $0.000^{*}$ \\
\hline
\end{tabular}

$\mathrm{P}<0.05$ is significant $(*=$ significant $)$.

- The results of the study showed correlation between the mean FEV1\% increased and the mean IL13 (correlation coefficient (R)=less than 1) in the same group and in different study groups before treatment which mean that when FEV1\% decrease, serum IL13 (pg/ml) increase (table 10a) fig. (12.a) and after 2 weeks of treatment which mean that when FEV1\% increases, serum IL 13 (pg/ml) decrease (table 10b) fig. (12b) There was significant correlation before treatment in different study groups and significant correlation after 2 weeks of treatment in different study groups except in group III.

Table (10a): Correlation between FEV1\% and IL 13 before treatment in Different Study Groups.

\begin{tabular}{|l|l|l|}
\hline Group & Correlation coefficient (R) & P-value \\
\hline I & -0.51 & $0.02^{*}$ \\
II & -0.67 & $0.001^{*}$ \\
III & -0.73 & $0.000^{*}$ \\
\hline
\end{tabular}

$\mathrm{P} \leq 0.05$ is significant $(*=$ significant $)$.

Table (10b): Correlation between FEV1\% and IL13 after treatment in different study groups 


\begin{tabular}{|l|l|l|}
\hline Group & Correlation coefficient (R) & P-value \\
\hline \hline I & -0.63 & $0.003^{*}$ \\
II & -0.50 & $0.02 *$ \\
III & -0.10 & 0.68 \\
\hline
\end{tabular}

$\mathrm{P} \leq 0.05$ is significant $(*=$ significant $)$

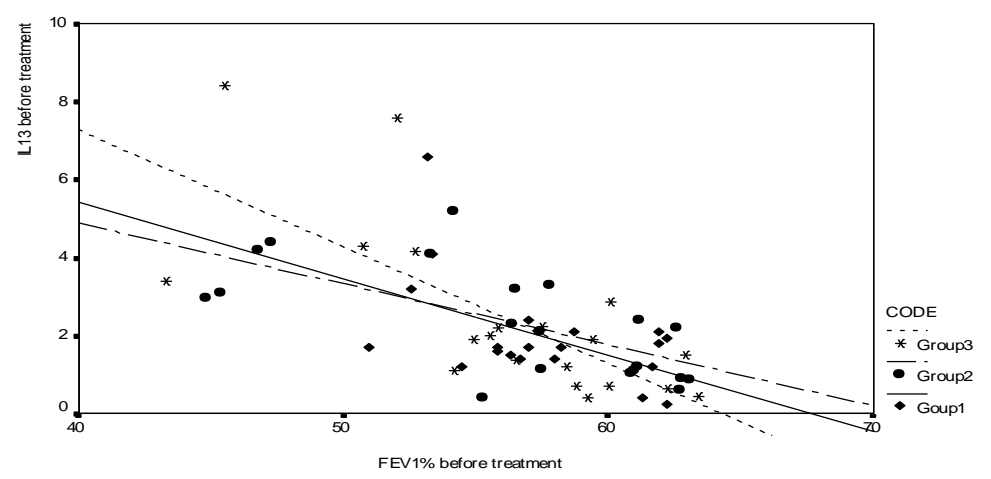

Fig. (12a)

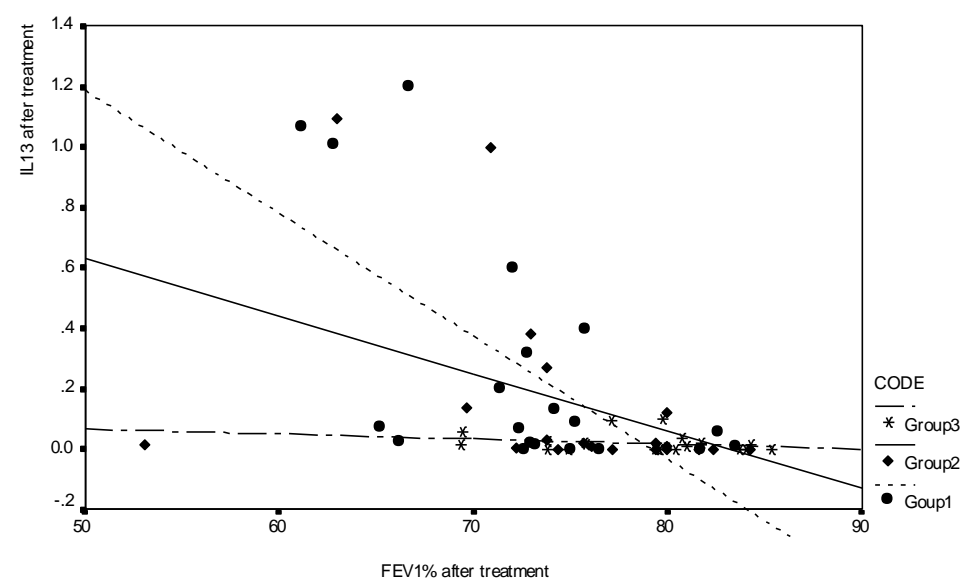

Fig. (12)

\section{Discussion}

At present, acupuncture is one of the most popular alternative therapies for asthma, and with the help of competent practitioners, it will be readily available in major population centers.

In the present study, percentage improvement of subjective parameters had been occurred in all groups. In group I cough had been reduced from $100 \%$ to $25 \%$, expectoration had been reduced from $80 \%$ to $25 \%$, breathlessness had been reduced from $100 \%$ to $40 \%$, and wheeze had been reduced from $70 \%$ to $25 \%$. In group III, cough showed a decrease from $100 \%$ to $15 \%$, expectoration decreased from $80 \%$ to $15 \%$, breathlessness decreased from $100 \%$ to $15 \%$ and wheeze decreased from $75 \%$ to $15 \%$.

Objective parameters showed another improvement, Group I; vesic ular breathing had dropped from $100 \%$ to $30 \%$ and rhonchi had dropped from $70 \%$ to $20 \%$ and in group III, vesicular breathing had dropped from $100 \%$ to $15 \%$ and rhonchi had dropped from $75 \%$ to $15 \%$. These parameters showed best results in group III, denoting that 
combination of bronchodilator and acupuncture effect were superior to ear acupuncture and/or bronchodilator alone and gave the best results.

There was also significant impro vement in ventilatory function tests in all groups as FEV1\% was increased in group I, $15.2 \%$, group II $18.6 \%$ and in group III $22.3 \%$ ) with better quality of life in all groups and also decrease the number of using B-agonist (Puffs) within the period of the treatment in combined groups, the best results were in group III (4.9 puffs / 2 weeks).

These results are in agreement with Zang $^{(11)}$ who studied 192 patients suffering from bronchial asthma, all of them were treated by acupuncture on Kongzui (Lu6) and Yuji (Lu10). The results revealed that there was $98.9 \%$ total effective rate of clinical remission plus marked subjective improvement in $76.5 \%$ of cases who were treated by acupuncture. The Zang ${ }^{(1)}$ found also that acupuncture treatment of bronchial asthma was considered very effective for those patients who have a history of drug allergy and also that the asthmatic symptoms in most of patients began to be improved after several acupuncture treatments with the dosage of the gradually reduced.

In our study many patients improved after the first setting. This may be due to that we used 5 somatic points in 3 settings/week for 2 weeks instead of 2 points used in Zang ${ }^{(11)}$ study. Adding ear acupuncture points (used 3-4 times/day) in our study gave better satisfactory and fast results.

Medici $^{(12)}$ discussed many publis hed studies on acupuncture and asthma. From these studies it emerges that short term effects of acupuncture are better documented than long term ones. Our study done within 2 weeks which was enough time for preoperative assess - ment of bronchial asthma and gave satisfactory results.

However, a study carried out by Joshi $^{(13)}$ suggested that acupuncture causes significant subjective improv ement with special respect to dyspnea, frequency, duration and severity of asthmatic attacks, with modest improv ement in objective parameter. Acupuncture has no role in treating acute attacks since it had weak bronchodilator effect, but it has an excellent prophylactic effect in the long run. But in our study we used a short course of treatment (2 weeks) for preoperative assessment for mild to moderate asthma.

Alekandrova $^{(14)}$ showed that treatment effects reached in 94 patients with bronchial asthma demonstrated that neurogenic, humoral and bioene rgetics responses to acupuncture result in reduction of bronchial hyporeactivity.

Pharmacologic treatment tended to have a greater effect than acupuncture alone. However, medication was signif icantly reduced when combined with acupuncture. As our study, medication was significantly reduced when comb ined with acupuncture (the mean number of puffs used/patient/2 weeks in group I was 26.6, in group II was 9.7 and in group III was 4.9). Jobst concluded that although more welldesigned studies are needed, there is no reason to withhold acupuncture treat ment from patients with bronchial asthma and chronic obstructive lung disease $^{(15)}$.

A review by $\boldsymbol{H e l m s}^{(16)}$ discussed 16 controlled studies; 9 studies concl uded that acupuncture is more effective than sham needling.

In a retrospective study 17 patients with long-standing history of asthma bronchiale were treated with acupuncture at the outpatient unit of the Department of Anaesthesia and inten - 
sive care in the university Hospital of Vienna Austria, Zwolfer et al. ${ }^{(17)}$ revea led that over $70 \%$ of patients with longstanding asthma reported a significant improvement of their ailment after 10 weeks of acupuncture treatment.

In the present study, we estimate the level of serum IL13 (Pg/ml) before treatment and after 2 weeks of treatm ents as the target for the severity of bronchial asthma; there was a decrease in the level of serum (IL13 Pg/ml) in the serum of blood of the patients after 2 weeks of treatment in all groups as follows, in group I decreased from 2.02 to 0.267 , group II decreased from 2.363 to 0.165 and group III decreased from 2.418 to 0.063 . The best result was decrease in the level of serum IL13 $(\mathrm{Pg} / \mathrm{ml})$ in group III and in group II. These results supported by many researches.

Naseer et al. ${ }^{(18)}$ found that an increase in expression of interleukin 13 mRNA has been reported in the airway mucosal in patients with atopic and nonatopic asthma. In addition, levels of IL13 together with IL4 increased following segmental allergen challenge of patients with asthma.

Levy et al. ${ }^{(19)}$ suggest that, in atopy, effector T-cells provide contactdependent activation signals to B-cells, and that these cells may induce $\operatorname{IgE}$ switching largely via secretion of IL13.

Yang et al. ${ }^{(20)}$ found that significantly decreased concentrations of serum $\operatorname{IgA}$ and total $\operatorname{Ig} \mathrm{A}$ (in saliva and in nasal secretion) and the level of $\operatorname{IgE}$ in sera after acupuncture treatment and that attacks of delayed and immediate allergic asthma could be effectively inhibited by acupuncture. However, the theory means little to a patient in the middle of an asthma attack.

Van der Pouw Kraan et al. ${ }^{(21)}$ Their results indicate that, at least in vitro, $\operatorname{IgE}$ production in allergic asthma patients is more dependent on IL13 than in non-atopics, due to enhanced IL13 production and to enhanced $\operatorname{IgE}$ in response to IL13.

Wills-Karp et al. $^{(22)}$ founded that IL-13 is critical to allergen-induces asthma patients and non-atopic controls, T-cells were polyclonally stimulated to obtain IL4, IL13 and subsequently IgE secretion, their results indicate that, at least in vitro, IgE production in allergic asthma patients is more dependent on IL13 than in non-atopics, due to enhanced IL13 production and to enhanced $\operatorname{IgE}$ in response to IL13 and that IL13 induces the pathophysio logical features of asthma in a manner that is independent of immunoglobulin $\mathrm{E}$ and eosinophils.

Li et al. ${ }^{(23)}$ studied the effects of $\mathrm{T}$ helper (Th2) cells cytokines on chemokine expression in the lung and IL13 potently induces eotaxin expre ssion by airway epithelial cells. Their study suggests that IL13 is an important mediator in the pathogenesis of asthma and therefore a potential target for asthma therapy.

In our study, side effects and complications of using acupuncture were nil. This may be due to that we explained and informed the patients and their relatives about the value of this work with reassurance during the setti ng and the use of stainless steel dispo sable acupuncture needles also we found that Egyptian patients were coo perative with acupuncture maneuvers.

Jobst ${ }^{(24)}$ has catalogued the side effects of acupuncture used in the treatment of asthma on the basis of reports from 16 published studies involving a total of 320 cases. Side effects were reported in only $23(7 \%)$ of the 320 cases, and these have generally been mild (e.g. vasovagal attacks, earache and gastro-intestinal symptoms) 
indicating that acupuncture therapy for asthma is generally safe. On the other hand, 5 cases of pneumothorax and one case of cardiac tamponade have been reported.

In conclusion: acupuncture is best reserved as an optional form of therapy that complements, rather than replaces conventional therapeutic modalities of proven effectiveness and also because nearly risk-free, relatively low-cost, non pharmacologic form of treatment. There is no reason to withhold acupuncture as a preoperative assessment for patients with bronchial asthma. But more controlled research is necessary for better understanding the range of its clinical application. Interleukin 13 can be used as important indicator for impr oving bronchial asthma preoperatively with other ventilatory function tests.

\section{References}

1. Busse WW and Parry ED. (1998): The biology of asthma in Fishman, pulmonary diseases and disorders $3^{\text {rd }}$ ed. McGrowHill P. 721-32.

2. Holgate ST, Hady C, Robinson C, Agins RM and Howarth, PH. (1986): The mast cell as a primary effector cell in the pathogenesis of asthma. J. Allergy Clin Immunol 77: 274-82.

3. Wenzel SE, Szefler SJ and Leung DyM (1997): Bronchoscopic evaluation of severe asthma: Persistent inflamma -tion associated with high dose glucoco rticoids Am J. Respir Crit Care Med. 156: 737-43.

4. Holgate ST, Bodey KS and Janerzic Release of RANTES, MIP-1 into asthmatic airways following endobr -onchial allergen challenge. Am J. Respir Crit Care Med. 156: 1377-83.

5. G. Zurawskin and Jan E. de VRies (1994): Interleukin 13, an interleukin 4-like cytokine that acts on monocytes and $\beta$ cells, but not on T cells". Immunol. Today, 15 No 1, 19.

6. Homer R,J, Zheng T, Chupp G, et al. (2002) : Pulmonary type II cellhypertrophy and pulmonary lipoport -einosis are feature of chronic IL-13 exposure. Am J. Physiol Fung Cell Mol. Physiol, Jul. 283 (1): 252-9.

7. Pekka J. Pontinen (1999): Anatomy and Physiology and Acupuncture patients:In Acupuncture, Treatment and Anaesthesia $5^{\text {th }}$ edition by Dr M. Salim: Lalazar Colony, Rawalipindi can tt. Pakistan: P23-64.

8. Stux G. (1987): Acupuncture, Textbook and Atlas: Gabriel Stux and Bruce Pomeranz.

9. Salim M. (1999): Acupuncture, Treatment and Anaesthesia: Salim M. $5^{\text {th }}$ editions. Lalazar Colony, Rawal -pindi Can tt. Pakistan.

10. Yang Jiasan (1988): The way to locate Acu-Points. Yong Jiasan; $2^{\text {nd }}$ edition. Printed by Foreign Languages Printing House; Beijing, China.

11. Zang (1990): Immediate anti-asthmatic effect of acupuncture in 192 cases of bronchial asthma, J. Tradit Chin Med, Jun 10 (2): 8993.

12. Medici TC (1994): Acupuncture and bronchial 
asthma. Schweiz Med Woche -nschr Suppl 62: 39-48

13. Joshi YM. (1992): Acupuncture in bronchial asthma. J. Assoc Physicians-India, May 40 (5): 327-31.

14. Aleksandrova RA. (1995): An analysis of the cupuncture treatment results inbronchial asthma patient. Vopr Kurortol Fizioter Lech Kult, MayJun; (3): 10-2.

15. Jobst KA. (1995): A critical analysis of acupuncture in pulmonary disease, efficacy and safety of the acupuncture needle. J. Altern Complement Med, Jan 1 (1): 57-85.

16. Helms JM. (1995): Acupuncture energyyetics, a clinical approach for physicians. Medical Acupuncture publishers, Berkeley, California 49.

17. Zwolfer W, KeznicklHillebrand W, Spacek A, Cartellieri $M$ and Grubhofer G. (1993): Beneficial effect of acupuncture on adult patients with asthma bronchial. Am J. Chin Med. 21 (2): 113-7.

18. Naseer T, Minshall EM and Leung DY. (1997): Expression of IL-12 and IL-13 mRNA in asthma and their modulation in response to steroid therapy. Am J. Respir Crit Care Med. 155: 845-51.

19. Levy F, Kristofic C, Heusser $C$ and Brinkmann V. (1997):
Role of IL13 in CD4 Tcell-dependent IgE production in a topy. Int Arch Allergy Immunol, Jan 112 (1): 49-58.

20. Yang Y, Chen H, Zhao C and Wang R. (1995): Studies on regulatory effects of acupuncture on mucosal secretory $\operatorname{IgA}$ in patients with allergic asthma. Chen Tzu Yen Chin 20 (2): 68-70.

21. Van Der Pouw Kraan TC, Van der Zee Js, Boeije LC, De Groot ER, Stapel SO and Aarden LA. (1998): The role of IL13 in $\operatorname{IgE}$ synthesis by allergic asthma patients. Clin Exp. Immunol, Jan 111 (1): 129-35.

22. Wills-Karp M, Luyimbazi J, Xu X, Schofield B, Neben TY, Karp CL and Donaldson DD. (1999): Interleukin-13, central mediator of allergic asthma. Science May 28, 284 (5419): 1431-4.

23. Li L, Xia Y, Nguyen A, Lai YH, Feng L, Mosmann TR and LoD (1999): Effects of the 2 cytokines on chemokine expression in the lung: IL13 potently induces cotaxin expression by airway epithelial cells. J. Immunol, Mar I; 162 (5): 2477-87.

24. Jobst KA (1996): Acupuncture in asthma and pulmonary disease: an analysis of efficacy and safety. J Altern Complement Med. Jan I (1): $57-85$. 


\section{تقييم طرق العلاج المختلفة قبل العمليات الجراحية فى مرضى الربو

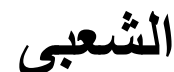

* كوثر عبد الرحمن عزام ـ ** سحر سعيد خطاب

أقسام *التذدير و**:الباتولجيا الإكلينكية ـ كلية الطب البنات ـ جامعة الأزهر

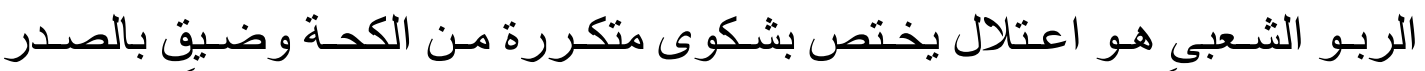

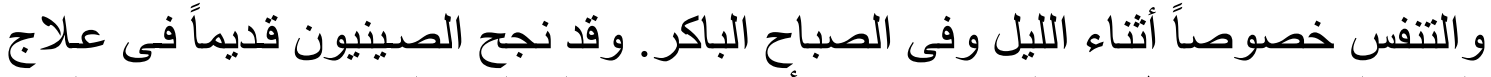

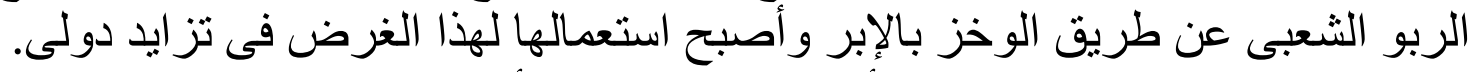

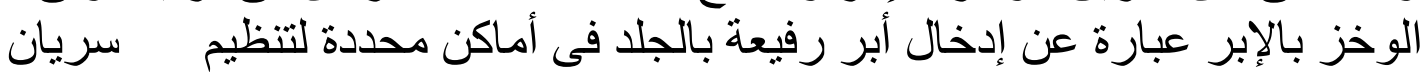

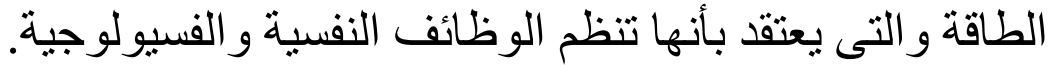

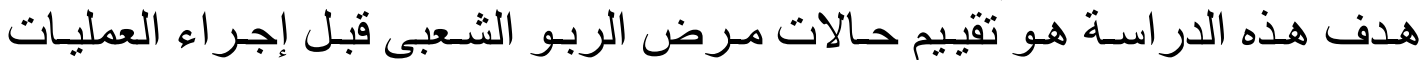

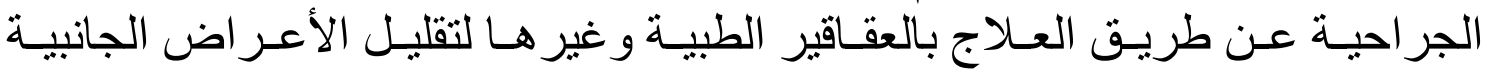

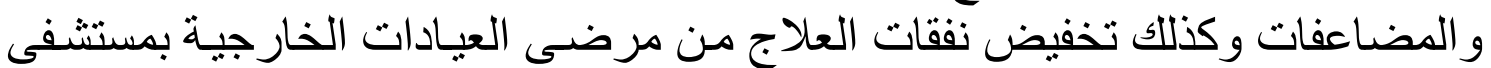

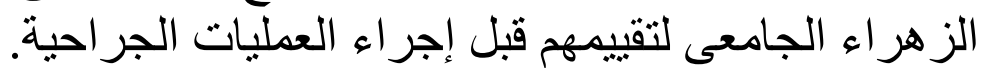

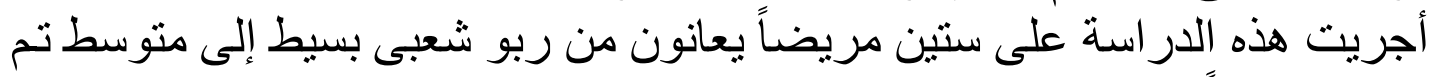
تقسيمهم عشو ائياً إلى ثلاثلث مجمو عات التئ. المجموعة الأولى: وتثمل عشرين مريضاً تم علاجهم عن طريق استخدام عقاقير

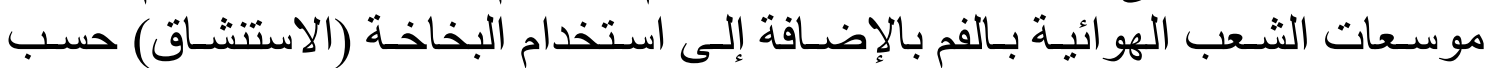

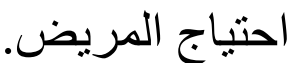
المجموعة الثانية: وتثمل عشرين مريضاً تم علاجهم عن طريق الوخز بالإذن الإن بالإضافة إلى العقاقير الطبية (مثل المجموعة وعة الأولى).

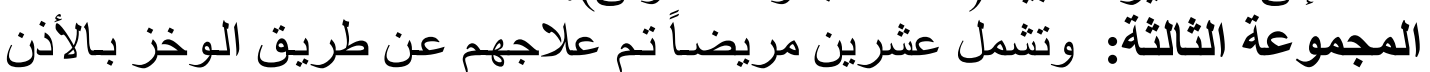

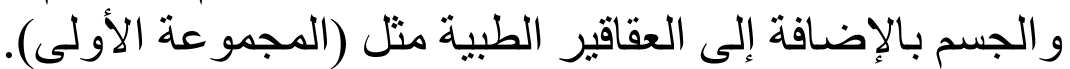

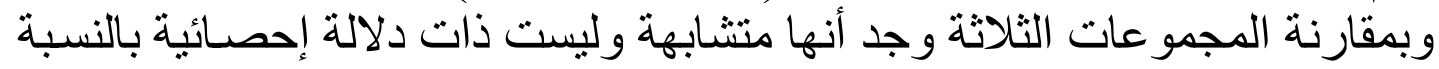

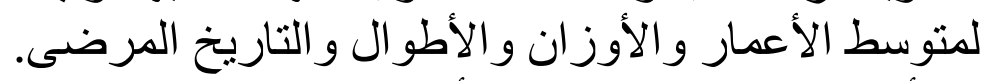

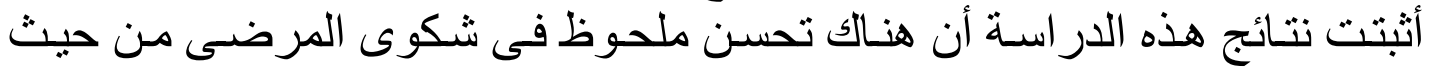

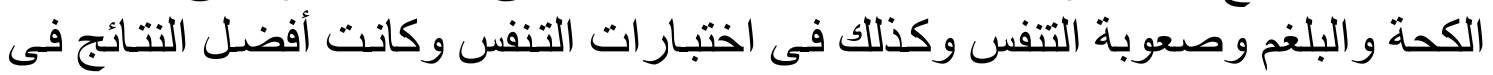

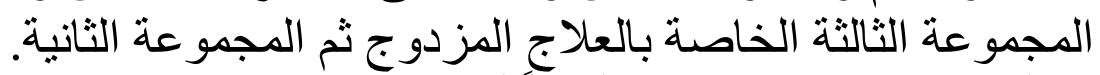

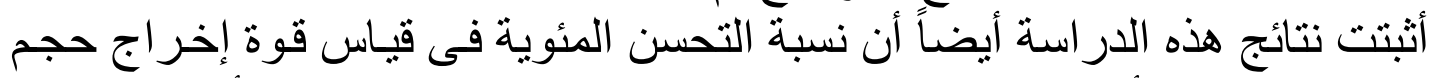

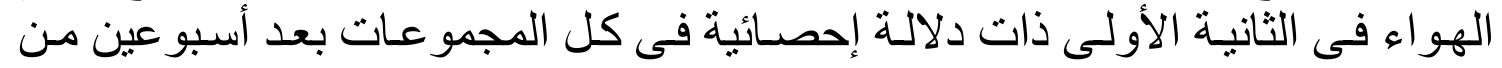

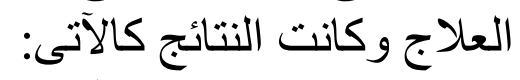

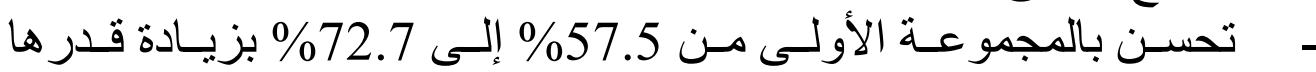
$\% 15.2$

- تحسـن بالمجموعـة الثنانيـة مـن 56.4 \% إلىى 75\% بزيــادة قـدرها $\% 18.6$ 
- تحسـن بالمجموعـة الثالثـة مسن 56.2\% إلـى 78.5\% بزيـادة قـدر ها $\% 22.3$

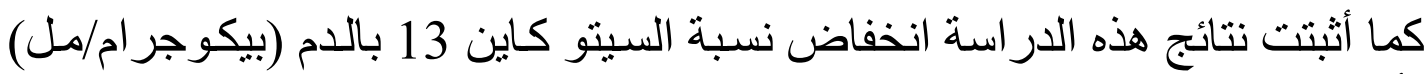

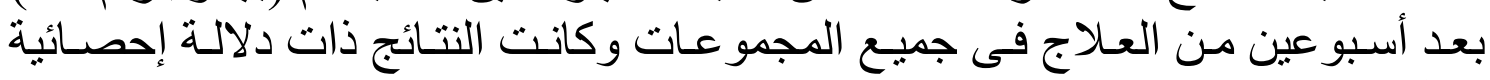

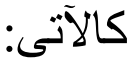

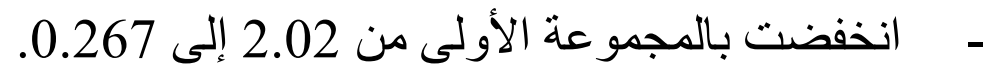
- انخفضت بالمجموعة الثانية من من 2.363 إلى 2.02165.

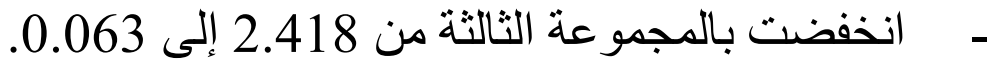

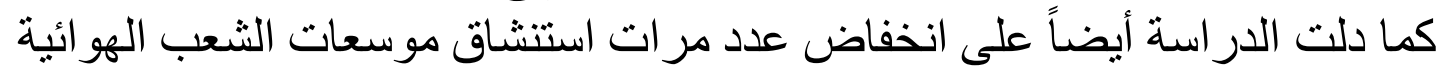

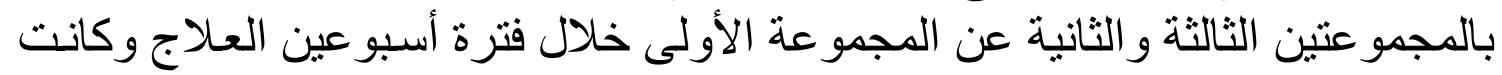
النتائ كالى. - - المجمو عة الأولى 26.6 مرة خلال الأسبو عين.

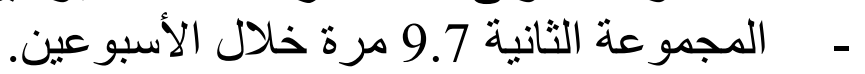

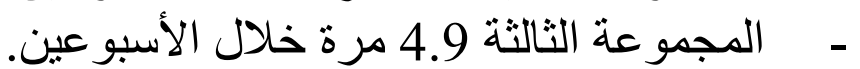

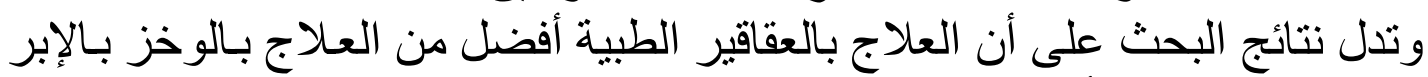

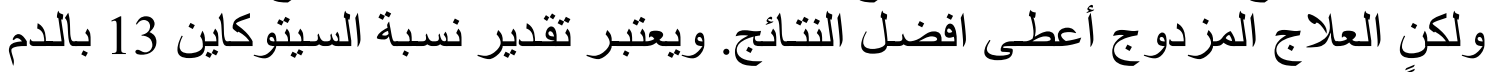

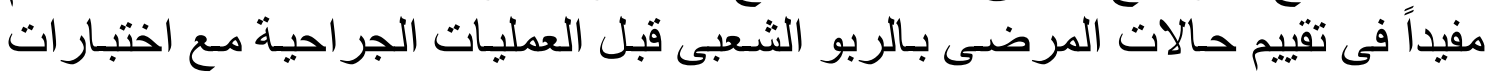

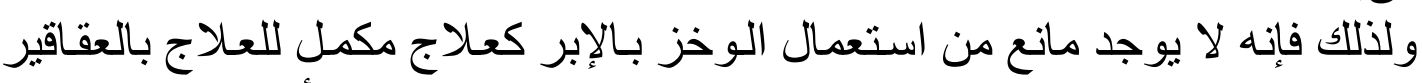

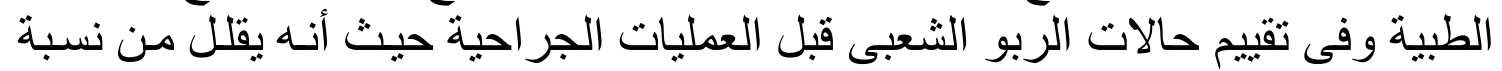

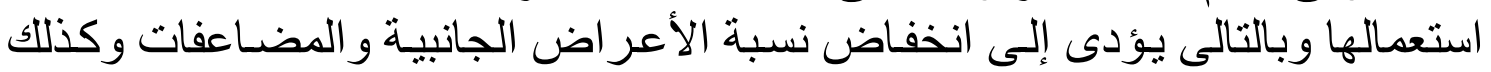
تخفيض نفقات العلاج. 